University of Nebraska - Lincoln

DigitalCommons@University of Nebraska - Lincoln

$4-30-2020$

\title{
Grain Marketing 2020: Survival and COVID-19
}

\author{
Robert Tigner \\ University of Nebraska-Lincoln, Robert.tigner@unl.edu \\ Jessica J. Groskopf \\ University of Nebraska-Lincoln, JJohnson@unl.edu
}

Follow this and additional works at: https://digitalcommons.unl.edu/ageconfarmmgmt

Part of the Agribusiness Commons, Entrepreneurial and Small Business Operations Commons, Management Information Systems Commons, Other Business Commons, Other Economics Commons, and the Other Immunology and Infectious Disease Commons

Tigner, Robert and Groskopf, Jessica J., "Grain Marketing 2020: Survival and COVID-19" (2020). Extension Farm and Ranch Management. 30.

https://digitalcommons.unl.edu/ageconfarmmgmt/30

This News Article is brought to you for free and open access by the Agricultural Economics Department at DigitalCommons@University of Nebraska - Lincoln. It has been accepted for inclusion in Extension Farm and Ranch Management by an authorized administrator of DigitalCommons@University of Nebraska - Lincoln. 


\section{Grain Marketing 2020: Survival and COVID-19}

\section{By Robert Tigner and Jessica Groskopf}

April 30, 2020

Let's state the obvious: this isn't a typical year and we all know it. For farmers, it is a survival year. Why? And what might be done to make it through to the other side of the COVID-19 pandemic? This article will discuss how to build a marketing strategy to assure that the farm continues to the next crop year.

\section{SITUATION}

COVID-19 and oil prices are the prominent factors that are influencing not only our agricultural economy, but also the broader economy. COVID-19 has caused world oil usage to decline starting in late 2019 (Figure 1). The U.S. Energy Information Agency (EIA) projects a decline of over 25\% worldwide. World production and consumption of oil stayed mostly in balance until Q4 of 2019 when COVID-19 presented and spread worldwide causing oil consumption to decline (Figure 2). Many countries prohibited non-essential land travel and air travel dropped to very low levels. This much reduced transportation fuels usage has unbalanced supply and demand and so far, oil production levels have not dropped to reflect reductions in demand. Oil prices likely will not recover until oil stockpiles begin to decline. Since corn usage is approximately $40 \%$ to ethanol, transportation and oil are linked to corn demand and price. When the situation will change is unpredictable.

Figure 1. World Oil Usage and Forecast

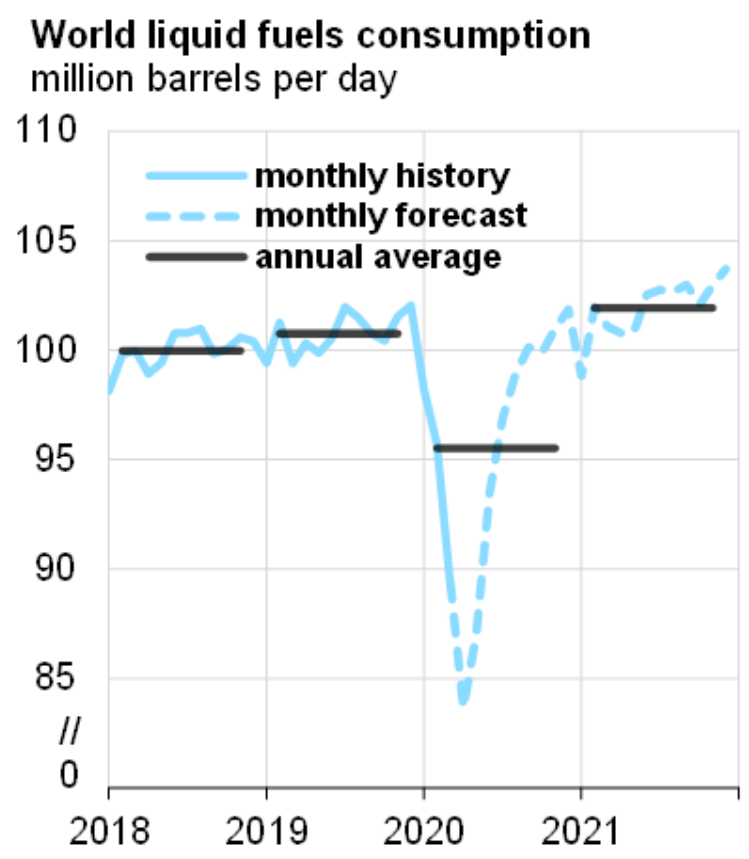

Source: Short-Term Energy Outlook, April 2020

\section{Components of annual change million barrels per day}

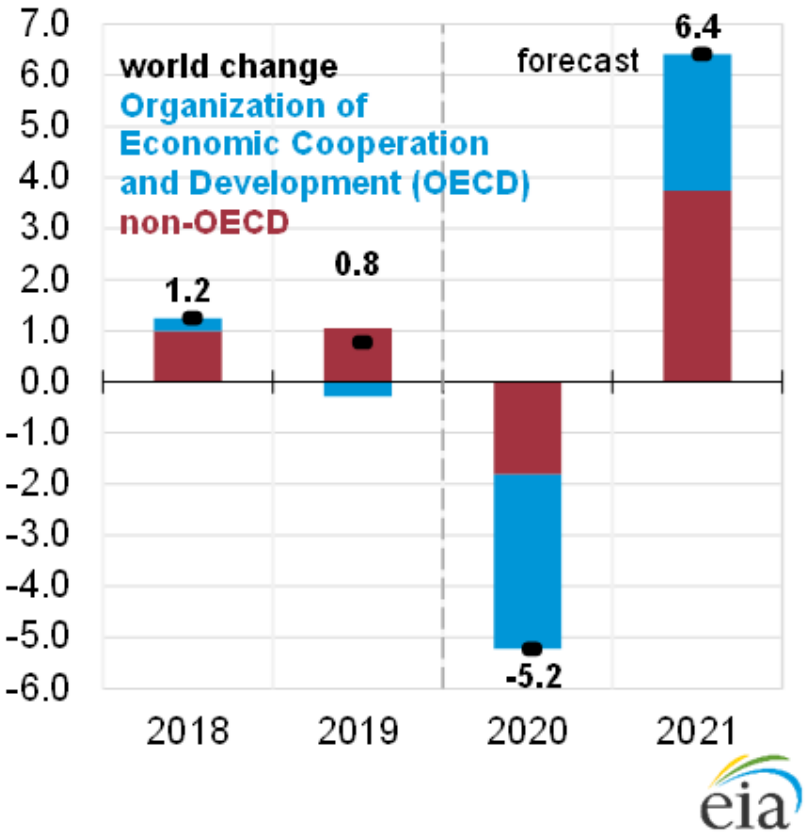


Figure 2. World Oil Product vs Use

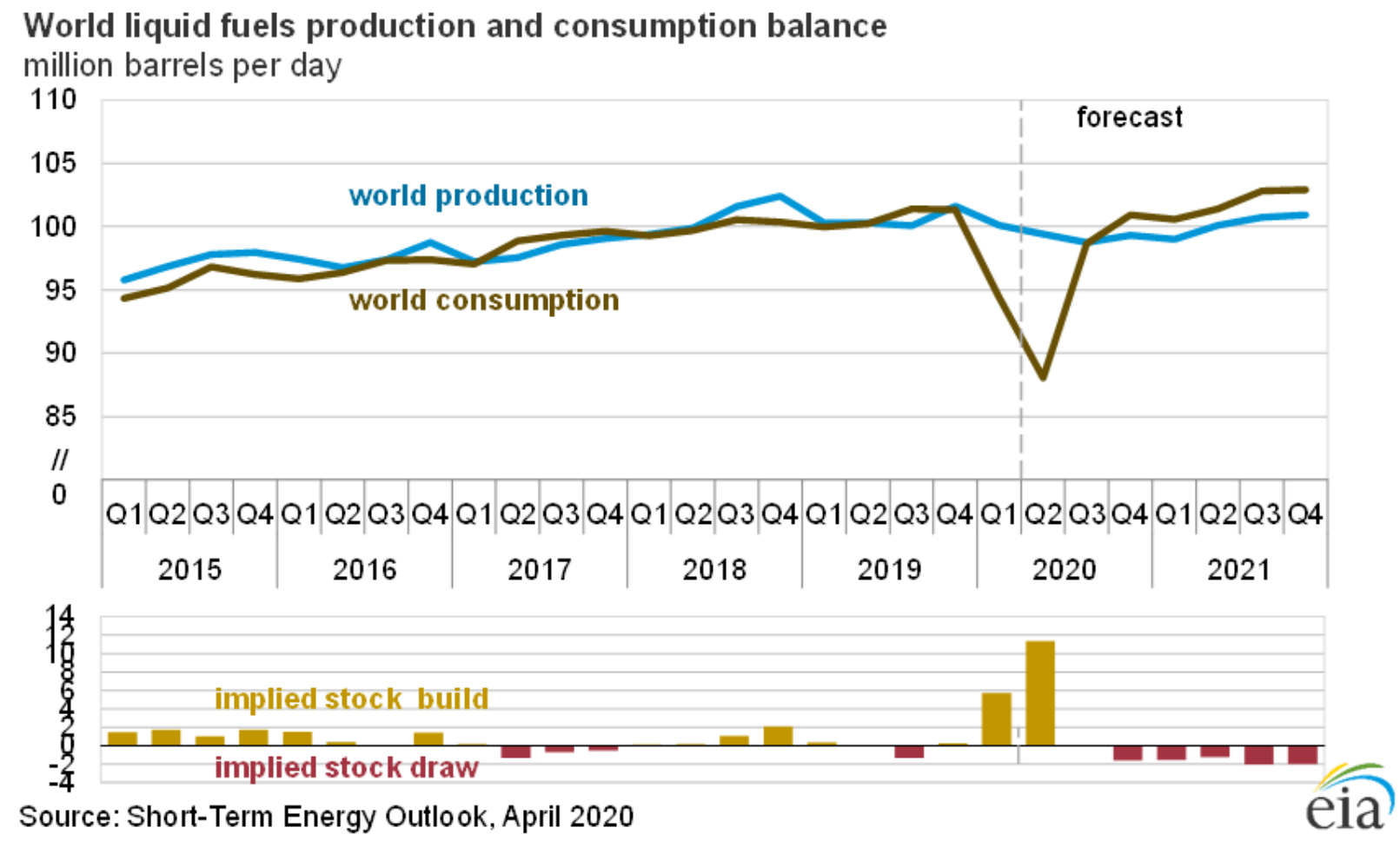

\section{MARKETING PLANNING}

This year's corn and soybean planting is underway in the Midwest with excellent planting weather across most of the region. Planting for most should be completed on time with minimal interruptions. That leads to the possibility of a good-to-excellent crop if weather after planting cooperates. If most of the nation meets or exceeds their actual production history (APH), this could place greater downward pressure on grain prices. You may be able to survive an average to high yield year, even with low prices. But what if you have a yield shortfall, and grain prices do not recover? With survival in mind, let's discuss steps in marketing planning.

First, review your input expenses. Cash flow planning earlier this year probably did not consider COVID19 impacts. Reassess that cash flow and adjust as appropriate. There are two sides to the cash flow expenses and income. Analyze each input expense to ensure you are achieving optimum - not maximum - yields based on current prices and input costs. Be certain to include cash expenses such as property taxes, lease payments and family living.

After reassessing your input expenses, review the potential income sources for your farm. The first source of income should be grain sales. Calculate a minimum cash price for each crop for a range of expected yields. This cash flow price should be the lowest price you need to obtain in order to pay for your input expenses. If these cash flow prices are above current or expected market prices, review costs again and make additional cuts without dramatically sacrificing yield. 
Another source of income may be off-farm income. The final source of income for your farm may be U.S. government programs. However, payment each farm or ranch may receive is unknown right now. Some of these programs include the Paycheck Protection Program, the Pandemic Unemployment Assistance program and cash payments from the U.S. Department of Agriculture. Farm Bill programs, and crop insurance may also provide additional income if markets remain low.

If no further costs can be reduced or off-farm income can be earned, make an appointment to meet with your lender to discuss what to do if higher pricing opportunities don't seem likely. In this environment, loan consolidation, especially at low interest rates, can be an appropriate action. Shorter-term loans might be collateralized with real estate to stretch loan payments and improve cash flow.

Next, develop a written plan that includes prices at or above your cash flow price-per-bushel and date triggers to help you sell throughout the year. Keep yourself accountable by sharing your plan with grain buyers, family and farm partners. The minimum prices and bushels planned to be sold need to bring in as much cash as you will need for the year. Crop producers should not ignore making sales at higher prices when available, but are trying to make sure they recapture all of their cash expenses first.

Finally, implement the marketing plan and do not let emotions derail the plan. Most years prices will follow a pattern where prices peak in June or July and later prices will trend down into harvest. In this economic environment, crop producers will want to maximize income. Trying to guess when the market peaks is difficult and likely to be incorrect, and may have already done so.

\section{CONCLUSION}

This year is shaping up to be a survival year for crop producers. Crop producers need to know at what crop price they will recapture all of the cash they will spend this year. Implementing a marketing plan to ensure that takes place is a survival strategy that can keep the farm business intact with no additional debt for a better year next year.

Sources:

1. Use of oil-U.S. Energy Information Administration (EIA). (n.d.). Retrieved April 22, 2020, from https://www.eia.gov/energyexplained/oil-and-petroleum-products/use-of-oil.php

2. Short-Term Energy Outlook-U.S. Energy Information Administration (EIA). (n.d.). Retrieved April 22, 2020, from https://www.eia.gov/outlooks/steo/report/global_oil.php

Robert Tigner and Jessica Groskopf are agricultural economists and extension educators in the Department of Agricultural Economics.

The University of Nebraska does not discriminate based on race, color, ethnicity, national origin, sex, pregnancy, sexual orientation, gender identity, religion, disability, age, genetic information, veteran status, marital status, and/or political affiliation in its programs, activities, or employment. 